\section{RSP}

http://www.rsp.fsp.usp.br/
Revista de Saúde Pública

\title{
Consequences of Chronic Non-Cancer Pain in adulthood. Scoping Review.
}

\author{
Rocío Cáceres-Matos' (iD), Eugenia Gil-García' iD, Sergio Barrientos-Trigo' iD, Ana María \\ Porcel-Gálvez' iD, Andrés Cabrera-León ${ }^{11, \mathrm{Il}, \mathrm{IV}}$ iD \\ I Universidad de Sevilla. Facultad de Enfermería, Fisioterapia y Podología. Departamento de Enfermería. \\ Sevilla, España \\ " Escuela Andaluza de Salud Pública. Granada, España \\ III Centro de Investigación Biomédica en Red de Salud Pública y Epidemiología (CIBERESP). Madrid, España \\ Iv Universidad de Granada. Instituto de Investigación Biosanitaria, ibs. Hospitales Universitarios de Granada. \\ Granada, España
}

\section{ABSTRACT}

OBJECTIVE: To examine and map the consequences of chronic pain in adulthood.

METHOD: Documents addressing the impact of chronic pain on the psychological and social spheres of people suffering from chronic pain, published in Spanish and English between 2013 and 2018, were included. Those who addressed pharmacological treatments, chronic pain resulting from surgical interventions or who did not have access to the full text were excluded. Finally, 28 documents from the 485 reviewed were included.

RESULTS: Studies show that pain is related to high rates of limitation in daily activities, sleep disorders and anxiety-depression spectrum disorders. People in pain have more problems to get the workday done and to maintain social relationships. Chronic pain is also associated with worse family functioning.

CONCLUSIONS: This review shows that limitations in the ability to perform activities of daily living, sleep, psychological health, social and work resources and family functioning are lines of interest in published articles. However, knowledge gaps are detected in areas such as the influence of having suffered pain in childhood or adolescence, the consequences of non-fulfillment of working hours and gender inequalities.

Correspondence:

Eugenia Gil-García

Calle Avenzoar 6, 41009, Sevilla,

España

E-mail: egil@us.es

Received: Apr 16, 2019

Approved: Oct 01, 2019

How to cite: Cáceres-Matos $R$,

Gil-García E, Barrientos-Trigo S,

Porcel-Gálvez AM,Cabrera-León A.

Consequences of Chronic

Non-Cancer Pain in adulthood. Rev

Saude Publica. 2020;54:39.

Copyright: This is an open-access article distributed under the terms of the Creative Commons Attribution License, which permits unrestricted use, distribution, and reproduction in any medium, provided that the original author and source are credited.
DESCRIPTORS: Adult. Adulthood. Chronic Pain. Cost of disease. Daily Activities. Quality of life. Review. 


\section{INTRODUCTION}

Pain is an unpleasant sensory and emotional experience that acts as a sign of biological alertness in the face of real or potential tissue damage ${ }^{1}$. It can be classified according to etiology, anatomical location or duration ${ }^{2}$. According to the latter, chronic non-cancer pain (CNCP) persists continuously or intermittently for a period of more than three months and is not associated with cancer processes ${ }^{3}$.

CNCP is considered a public health problem that affects $20 \%$ to $35 \%$ of the world's population $^{4}, 19 \%$ of the European population ${ }^{5}$ and $17 \%$ of the Spanish population ${ }^{6}$. When pain persists for long periods of time, it loses its protective purpose ${ }^{7}$ and becomes the result of a complex process in which biological, psychological and sociocultural ${ }^{8}$ factors interact with each other'. Several international organizations, such as the European Pain Federation or the International Association for the Study of Pain, consider that a change of perspective in the assessment and treatment of pain is necessary, being addressed as an entity in itself ${ }^{10}$, in which the family, social and cultural context that the person lives is considered ${ }^{11}$.

In the last ten years, scientific production on the repercussions of pain has increased. Numerous studies state that the perception and appreciation of CNCP affect sleep ${ }^{12}$ or limitations of daily activity ${ }^{13}$, but also psychological and social factors such as anxiety, depression $^{14}$, self-esteem $^{15}$, coping $^{16}$, resilience ${ }^{13}$, social and family support ${ }^{7}$ and/or use of toxic substances ${ }^{14}$.

Therefore, we consider it necessary to know the individual and social consequences that $\mathrm{CNCP}$ has on the adult population. For this, we conducted a Scoping Review of the scientific literature. Our goal is to examine and map the consequences of chronic pain in adulthood.

\section{METHODS}

The Scoping Review methodology is used to map the scientific literature and detect areas of study that are not sufficiently researched ${ }^{16}$. To accomplish this, we used the methodological framework proposed by Arksey and O'Malley ${ }^{17}$ and the Joanna Briggs Institute Reviewer's Manual ${ }^{18}$. Although the Scoping Review methodology does not require quality assessment, several authors consider it a strength ${ }^{19}$, as it allows to make recommendations for clinical practice ${ }^{20}$.

In view of these considerations, we assessed the level of evidence (LE) and the degree of recommendation (DR) of the studies included in accordance with the Scottish Intercollegiate Guidelines Network ${ }^{21}$. In this case, LE and DR scores are related. Thus, for an investigation with NE 1++; 1+ or 1- is considered extremely recommended (DR A); for NE 2++, 2+ or 2the recommendation rating would be favorable (DR B), and for LE 3 and 4 the degrees of recommendation would be favorable, but not conclusive (DR C), and it is not recommended or disapproved (DR D), respectively.

\section{Databases and research strategy}

The search in the literature was performed in four scientific databases (CINAHL, PubMed, Scopus and Web of Science) and in gray literature deposits (Research Repository of the University of Seville IDUS, TESEO, Openthesis, Opengrey, Grey Literature Report, American Pain Society, European Pain Federation, and International Association for the Study of Pain).

They were held between November and December 2018 with the following search strategy: ("chronic pain" OR "persistent pain" OR "long term pain") and (adult") AND (impact" OR influenc* OR cause* OR outcome* OR result* OR consequence* OR effect* OR repercussion*).

As inclusion criteria, documents addressing the biopsychosocial consequences of chronic non-cancer pain were considered: 1 ) documents addressing the biopsychosocial 
consequences of chronic non-cancer pain; (2) in adults between 18 and 65 years old, not hospitalized; 3) published between 2013 and December 2018 and 4) written in Spanish or English.

Exclusion criteria were: 1) documents dealing with pharmacological treatments;2) documents that address people with chronic non-cancer pain resulting from neurodegenerative diseases, chronic infectious diseases or cognitive impairment and 3) documents that did not have access to the full text.

\section{Screening}

After the removal of duplicate articles in the research, the selection process was performed, evaluating the relevance of the studies identified. This process was performed by two reviewers independently.

In the first phase, reviewers assessed the titles and abstracts found to exclude articles that did not meet the inclusion and exclusion criteria. Later, they reviewed their contents in full text and decided which ones were included in the data extraction phase. In case of disagreement about the inclusion of an article between the two reviewers, it was discussed with the rest of the research team until consensus was reached.

\section{Data extraction and analysis}

Team members produced a document that served as a model for the extraction of information from the article to be standardized. In addition, they developed a protocol to systematize the work procedure. Two of the team members independently collected information about each of the articles (authors' names, year and country of publication, study objective and methodology, sample size and characteristics, intervention, main results obtained and key points). All team members discussed the information in cases of disagreement until consensus was reached.

\section{RESULTS}

After the review, 485 articles whose titles met the inclusion criteria were obtained. The search for gray literature produced 60 documents. Once duplicates were removed, 285 titles and abstracts were reviewed using the inclusion and exclusion criteria. Exactly 170 full texts were recovered for screening. After reviewing the full texts, 142 were excluded, because they did not report the theme of the study, remaining 28 documents for analysis (Figure). The studies included were classified into four areas based on the effects of chronic pain: activities of daily living (ADL); sleep (S); psychological health (PH) and socio-labor and family consequences (SLFC) (Table).

\section{Consequences on everyday activities}

Chronic Non-Cancer Pain increases in disability and limitation in daily activities ${ }^{22-26}$. People tend to avoid activities that cause or increase the severity of pain, leading to a decrease in activity levels compared with healthy people ${ }^{22-24,27}$. In this sense, when pain interferes with the ability to perform daily activities, people tend to show a negative perception of themselves due to lower physical capacity and misunderstanding of people in their environment ${ }^{28}$, a fact that translates into greater catastrophizing in the face of pain ${ }^{29}$. In turn, studies indicate that people with CNCP spend more time sitting and less time standing, and that an increase in physical activity during the afternoon is related to the decrease in activities of daily living in the evening ${ }^{30}$.

A less active lifestyle is also associated with persistence and more severe pain levels ${ }^{31}$, comorbidity of chronic diseases such as obesity or diabetes ${ }^{30,32}$, more difficulty in self-care and increased use of health services ${ }^{33}$. 


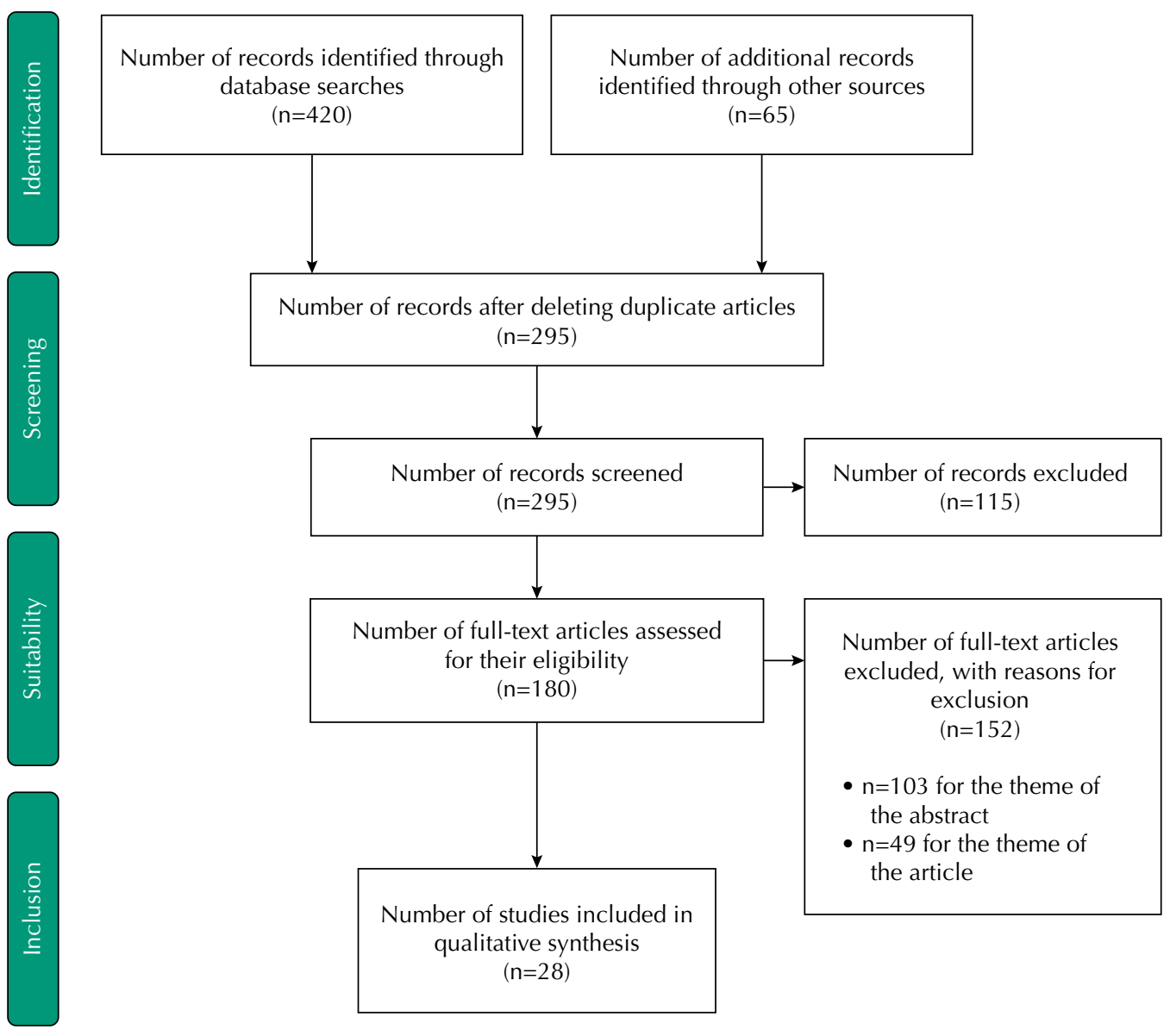

Figure. Consequences of chronic non-cancer pain in adulthood. Scoping Review.

\section{Consequences of sleep}

Sleep problems are a common consequence in people with $\mathrm{CNCP}^{29}$. Studies suggest pain management improve sleep quality by up to $14 \%$. The results indicate there is a circular and dynamic interrelation in which pain causes sleep disorders, which, in turn, increase pain intensity ${ }^{34-36}$.

Other studies state that between 50 and $88 \%$ of people meet the diagnostic criteria for sleep disorders ${ }^{36,37}$ and have abnormal brain activity during sleep ${ }^{38}$. In a study conducted by Cranford et al..$^{37}$, it was reported that $30 \%$ of the participants had sleep problems every night and/or several times a night. The most common changes are difficulty in starting or maintaining sleep, waking up earlier, having fragmented or no-restorative sleep $^{34}$, and higher levels of fatigue during the day; more evident symptoms in women than in men ${ }^{38}$.

Sleep disorders due to $\mathrm{CNCP}$ are also related to limitation in performing daily activities and disability $^{34}$. Andrews et al. ${ }^{4}$ noted that people performing more intense activities during the day suffer more pain and stay awake longer periods at night.

On the other hand, some people resort to using cannabis to improve the quality of their sleep. Cranford et al..$^{37}$ found that $80 \%$ of study participants responded to having used cannabis in the last six months to improve the quality of their sleep, showing a positive opinion about them. However, in $65 \%$ of cases people have developed cannabis dependence.

\section{Consequences on psychological health}

$\mathrm{CNCP}$ is associated with suffering from mental illness ${ }^{4}$. Different studies have investigated this relationship, finding that mental illnesses are present in $75.3 \%$ of cases of pain ${ }^{4,14}$, and 
Table. Main characteristics of the studies included in the review.

\begin{tabular}{llll}
\hline $\begin{array}{l}\text { Authors, } \\
\text { year, country }\end{array}$ & Objective & Methodology/sample Intervention & Key \\
\hline
\end{tabular}

Compare pain, emotional state and

Altug et al. disability level in $2015 \quad$ patients with chronic Turkey cervical pain and low back pain.

Examines the role

Akbari of individual and

et al. family variables

2016 in understanding

Iran chronic pain related to

disability.

Examine the

Andrews association between

et al. daily physical activity

Australia

and sleep in people with chronic pain.

Understand the

Bailly et al. experiences of patients $2015 \quad$ living with low back

France pain. Monocentric qualitative study.
- Visual Analogue Scale (VAS)

Cross-sectional study. - Owestry Disability Index (ODI)

$\mathrm{N}=100$ patients $\quad$ Neck Disability Index (NDI)

- Beck Depression Inventory (BDI)

No significant difference was found for the intensity and duration of pain between the low back pain group and the group with neck pain. Pain duration, emotional

state and disability level in patients with low back pain were worse than in patients with neck pain.

\section{- Visual Analogue Scale (VAS) \\ - Tampa Scale of Kinesiophobia (TSK \\ - Pain Catastrophizing Scale (PCS) \\ Cross-sectional study. $\mathrm{N}=142$ people \\ - Roland Morris Disability Questionnaire (RDQ) \\ - Anxiety Stress Scales (DASS) \\ - Family Assessment Device (FAD)}

Prospective observational study. $\mathrm{N}=50$ people

- Demographic questionnaire

- Visual Analogue Scale (VAS)

Monocentric

qualitative study.

$\mathrm{N}=25$ people $(11$

men and 14 women)
- Semi-structured interview and focus groups

Family dysfunction can

contribute to catastrophic thinking, which in turn contributes to the inability of patients, increasing the fear of movement and depression.

Individuals who claimed to have a greater number of pain points had longer periods of vigil at night.

ADL

The participants reported negative perception in social interactions, with shame and frustration in relation to their difficulties in performing daily activities. They felt misunderstood and unsupported due to the absence of visible signs of the condition.

Women showed higher overall activity than males. Higher levels of pain resulted in worse results in

$\begin{array}{ll}\text { Cross-sectional study } & \text { Multidimension } \\ \mathrm{N}=472 \text { people } & \text { Inventory (MPI) }\end{array}$

- Visual Analog Scale (VAS) component of pain in emotional, social and daily functioning.

Cabrera- Evaluate the Perona association between et social comparison,

2017

Spain catabolism and specific health outcomes.

Cross-sectional study. $\mathrm{N}=131$ people
Evaluate the prevalence of suicidal ideation among a sample of patients with fibromyalgia.
Cross-sectional study. $\mathrm{N}=373$ people

et al.

Spain
Proving that sleep problems in people with chronic pain increase the risk of initiating depression.
- Fibromyalgia Impact Questionnaire

- The Beck Depression Inventory (BDI)

- The Pittsburgh Sleep Quality Index

- The Brief Pain Inventory (BPI)

- SF-12 Health Survey

Prospective cohort - Jenkins Sleep Questionnaire study.

$\mathrm{N}=2,622$ people
- Jenkins Sleep Questionnaire Scale (HADS) et al.

UK all areas of functioning.

A positive correlation was found between catabolism and functional deficiency, psychological distress, anxiety and depression in fibromyalgia.

$48 \%$ of people with chronic pain reported having suicidal thoughts and 31 percent attempted suicide. There were no differences in the age or duration of the disease among patients without suicidal ideation, suicidal thinking and suicidal behavior.

Sleep problems can lead to depression three years after it begins. Treatments may include preventing or treating sleep problems, as well as focusing on pain treatment. 
Table. Main characteristics of the studies included in the review. (Continuation)

\begin{tabular}{|c|c|c|c|c|c|c|c|}
\hline $\begin{array}{l}\text { Authors, } \\
\text { year, country }\end{array}$ & Objective & Methodology/sample & Intervention & Results & $\begin{array}{c}\text { Key } \\
\text { points }\end{array}$ & LE & DR \\
\hline $\begin{array}{l}\text { Campbell } \\
\text { et al. } \\
2015 \\
\text { New } \\
\text { Zealand }\end{array}$ & $\begin{array}{l}\text { Document the } \\
\text { prevalence and } \\
\text { correlations of } \\
\text { chronic pain and } \\
\text { suicide, estimating the } \\
\text { contribution of chronic } \\
\text { disease to suicide. }\end{array}$ & $\begin{array}{l}\text { Population study. } \\
\mathrm{N}=8,841 \text { people. }\end{array}$ & $\begin{array}{l}\text { - Australian National Mental } \\
\text { Health Survey. }\end{array}$ & $\begin{array}{l}\text { The chances of suicide were } \\
\text { two to three times higher in } \\
\text { people in pain. Sixty-five } \\
\text { percent of people who have } \\
\text { tried to kill themselves in the } \\
\text { last } 12 \text { months had a history } \\
\text { of chronic pain. }\end{array}$ & $\mathrm{S}$ & $3 b$ & B \\
\hline $\begin{array}{l}\text { Castro } \\
\text { et al. } \\
2014 \\
\text { Spain }\end{array}$ & $\begin{array}{l}\text { Evaluate sleep } \\
\text { quality and the } \\
\text { prevalence of severe } \\
\text { depressive disorder } \\
\text { and generalized } \\
\text { anxiety disorder in } \\
\text { patients with chronic } \\
\text { musculoskeletal pain. }\end{array}$ & $\begin{array}{l}\text { Cross-sectional study. } \\
\mathrm{N}=39 \text { people }\end{array}$ & $\begin{array}{l}\text { - International Neuropsychiatric } \\
\text { Interview. } \\
\text { - Pittsburgh Questionnaire } \\
\text { - Montgomery-Asberg } \\
\text { Depression Scale }\end{array}$ & $\begin{array}{l}69.2 \% \text { of the sample } \\
\text { had severe depressive } \\
\text { disorder and/or } 65.5 \% \text { had } \\
\text { generalized anxiety disorder. } \\
\text { No statistically significant } \\
\text { differences in sleep quality } \\
\text { were found between groups } \\
\text { treated with potent opioids } \\
\text { and treated with smaller } \\
\text { opioids/anti-inflammatory } \\
\text { drugs. }\end{array}$ & $\begin{array}{l}\mathrm{ADL}, \\
\mathrm{S}\end{array}$ & 4 & $\mathrm{C}$ \\
\hline $\begin{array}{l}\text { Danya } \\
\text { et al. } \\
2015 \\
\text { France }\end{array}$ & $\begin{array}{l}\text { Explore the } \\
\text { relationship between } \\
\text { time perspective } \\
\text { and psychological } \\
\text { difficulties. }\end{array}$ & $\begin{array}{l}\text { Cross-sectional study. } \\
\mathrm{N}=264 \text { people }\end{array}$ & $\begin{array}{l}\text { - Zimbardo Time Perspective } \\
\text { Inventory (ZTPI) } \\
\text { - Pain Beliefs and Perceptions } \\
\text { Inventory (PBPI) } \\
\text { - Hospital Anxiety and Depression } \\
\text { Scale (HADS) }\end{array}$ & $\begin{array}{l}\text { Patients with children were } \\
\text { more depressed, those at the } \\
\text { educational level were more } \\
\text { anxious, and those who } \\
\text { were unemployed during } \\
\text { the disease had higher levels } \\
\text { of depression. }\end{array}$ & $\mathrm{S}, \mathrm{PH}$ & 4 & $\mathrm{C}$ \\
\hline $\begin{array}{l}\text { De Sola } \\
\text { et al. } \\
2017 \\
\text { Spain }\end{array}$ & $\begin{array}{l}\text { Determine prevalence } \\
\text { and factors related to } \\
\text { medical leave and loss } \\
\text { of employment among } \\
\text { people suffering from } \\
\text { chronic pain. }\end{array}$ & $\begin{array}{l}\text { Cross-sectional study. } \\
\mathrm{N}=1,543 \text { people }\end{array}$ & - Telephone survey & $\begin{array}{l}\text { The prevalence of medical } \\
\text { leave due to CP in the Spanish } \\
\text { population was } 4.21 \% \text {, being } \\
\text { more prevalent in people } \\
\text { who need help dressing and } \\
\text { caring, taking medications } \\
\text { and/or with higher schooling. } \\
\text { The prevalence of job loss } \\
\text { was } 1.8 \% \text {. }\end{array}$ & $\begin{array}{l}\mathrm{PH}, \\
\text { SLFC }\end{array}$ & 4 & $\mathrm{C}$ \\
\hline $\begin{array}{l}\text { Ditre et al. } \\
2013 \\
\text { USA }\end{array}$ & $\begin{array}{l}\text { Evaluate the } \\
\text { importance of } \\
\text { pain-related anxiety } \\
\text { in relation to tobacco } \\
\text { dependence in a } \\
\text { sample of smokers } \\
\text { with chronic pain. }\end{array}$ & $\begin{array}{l}\text { Cross-sectional study. } \\
\mathrm{N}=129 \text { people }\end{array}$ & $\begin{array}{l}\text { - Pain Anxiety Symptoms } \\
\text { Scale (PASS-20) } \\
\text { - Wisconsin Inventory of Smoking } \\
\text { Dependence Motives (WISDM) } \\
\text { - Chronic Pain Screener } \\
\text { - Graded Chronic Pain Scale (GCPS) } \\
\text { - Generalized Anxiety } \\
\text { Disorder (GAD-7) } \\
\text { - Fagerström Test for Nicotine } \\
\text { Dependence (FTND) }\end{array}$ & $\begin{array}{l}\text { Pain-related anxiety was } \\
\text { strongly associated with } \\
\text { tobacco dependence. } \\
\text { Smokers may be at risk of } \\
\text { maintaining and exacerbating } \\
\text { their dependence on } \\
\text { tobacco, possibly due to } \\
\text { individual differences in } \\
\text { pain-related anxiety. }\end{array}$ & $\mathrm{S}$ & 4 & $\mathrm{C}$ \\
\hline $\begin{array}{l}\text { Ferreira- } \\
\text { Valente } \\
\text { et al. } \\
2014 \\
\text { Portugal }\end{array}$ & $\begin{array}{l}\text { Evaluate coping } \\
\text { responses, beliefs, } \\
\text { and social support to } \\
\text { adapt positively. }\end{array}$ & $\begin{array}{l}\text { Observational study. } \\
\mathrm{N}=324 \text { people }\end{array}$ & $\begin{array}{l}\text { - Numerical Rating Scale (NRS) } \\
\text { - Portuguese Brief Pain Inventory } \\
\text { Interference Scale (P-BPI) } \\
\text { - Physical Component Summary (MCS) } \\
\text { - Portuguese Pain Self-Efficacy } \\
\text { - } \text { Suestionnaire (P-PSEQ) } \\
\text { Scial Support Satisfaction } \\
\text { - Pcale (ESSS) } \\
\text { Portuguese 2-item per Scale Coping } \\
\text { Strategies Questionnaire (CSQ-14) }\end{array}$ & $\begin{array}{l}\text { Coping responses } \\
\text { and perceived social } \\
\text { support were related to } \\
\text { interference in pain and } \\
\text { psychological functioning. } \\
\text { Coping responses were } \\
\text { positively associated with } \\
\text { pain interference and } \\
\text { negatively to physical and } \\
\text { psychological functioning. }\end{array}$ & $\begin{array}{l}\mathrm{ADL} \\
\mathrm{S}, \mathrm{PH}\end{array}$ & 4 & $\mathrm{C}$ \\
\hline $\begin{array}{l}\text { Henne } \\
\text { et al. } \\
2015 \\
\text { Australia }\end{array}$ & $\begin{array}{l}\text { Explore the } \\
\text { relationship } \\
\text { between persistent } \\
\text { pain, anguish, and } \\
\text { emotional connection. }\end{array}$ & $\begin{array}{l}\text { Cross-sectional study. } \\
\mathrm{N}=388 \text { women }\end{array}$ & $\begin{array}{l}\text { - The McGill Pain Questionnaire } \\
\text { (SF-MPQ) } \\
\text { - Depression, anxiety and stress } \\
\text { (DASS-21- short form) }\end{array}$ & $\begin{array}{l}\text { Many women with chronic } \\
\text { pain have difficulties in } \\
\text { emotional connection that } \\
\text { attribute to the experience of } \\
\text { persistent pain. }\end{array}$ & $\mathrm{S}$ & 4 & $\mathrm{C}$ \\
\hline $\begin{array}{l}\text { Inoue et al. } \\
2015 \\
\text { Japan }\end{array}$ & $\begin{array}{l}\text { Estimate the } \\
\text { prevalence of chronic } \\
\text { pain in Japan, analyze } \\
\text { the associated } \\
\text { factors and evaluate } \\
\text { social burden due to } \\
\text { chronic pain. }\end{array}$ & $\begin{array}{l}\text { Cross-sectional study } \\
\mathrm{N}=6,000 \text { people }\end{array}$ & $\begin{array}{l}\text { - 11-point Numerical Rating } \\
\text { Scale (NRS) }\end{array}$ & $\begin{array}{l}\text { Chronic pain worsens with } \\
\text { environmental factors. People } \\
\text { who exercise had lower rates } \\
\text { of pain. Women suffered } \\
\text { more pain than men. Elderly, } \\
\text { living alone and unemployed } \\
\text { were also associated with } \\
\text { chronic pain. }\end{array}$ & $\mathrm{PH}$ & 4 & $\mathrm{C}$ \\
\hline
\end{tabular}


Table. Main characteristics of the studies included in the review. (Continuation)

\begin{tabular}{|c|c|c|c|c|c|c|c|}
\hline $\begin{array}{l}\text { Authors, } \\
\text { year, country }\end{array}$ & Objective & Methodology/sample & Intervention & Results & $\begin{array}{c}\text { Key } \\
\text { points }\end{array}$ & LE & DR \\
\hline $\begin{array}{l}\text { Jensen } \\
\text { et al. } \\
2015 \\
\text { Denmark }\end{array}$ & $\begin{array}{l}\text { Describe the } \\
\text { associations between } \\
\text { demographics and } \\
\text { health-related quality } \\
\text { of life of patients with } \\
\text { chronic non-cancer } \\
\text { pain. }\end{array}$ & $\begin{array}{l}\text { Cohort study } \\
N=1,176 \text { people }\end{array}$ & $\begin{array}{l}\text { - Hospital Anxiety and Depression } \\
\text { Scale (HADS) } \\
\text { - Short-Form } 36 \text { Bodily Pain } \\
\text { Scale (SF-36). }\end{array}$ & $\begin{array}{l}\text { Patients with chronic pain } \\
\text { scored less in all domains, } \\
\text { especially in physical } \\
\text { activity, pain level and } \\
\text { vitality. } 75 \% \text { of patients } \\
\text { assess that their physical } \\
\text { health affects their work and/ } \\
\text { or daily activity. }\end{array}$ & $\mathrm{PH}$ & $1 b$ & A \\
\hline $\begin{array}{l}\text { Karaman } \\
\text { et al. } \\
2014 \\
\text { Turkey }\end{array}$ & $\begin{array}{l}\text { Examine the } \\
\text { prevalence and } \\
\text { relationship between } \\
\text { sleep disorders and } \\
\text { chronic pain. }\end{array}$ & $\begin{array}{l}\text { Observational study. } \\
\mathrm{N}=2,635 \text { people }\end{array}$ & $\begin{array}{l}\text { - Visual Analogue Scale (VAS) } \\
\text { - Pain Sleep Quality Index (PSQI) }\end{array}$ & $\begin{array}{l}33 \% \text { of patients with chronic } \\
\text { pain between } 20 \text { and } 30 \\
\text { years and } 47.8 \% \text { between } \\
60 \text { and } 70 \text { years presented } \\
\text { worse sleep quality. }\end{array}$ & $\mathrm{ADL}$ & 4 & $\mathrm{C}$ \\
\hline $\begin{array}{l}\text { Mun et al. } \\
2017 \\
\text { USA }\end{array}$ & $\begin{array}{l}\text { Test the effect of pain } \\
\text { expectancy with pain } \\
\text { after pain. }\end{array}$ & $\begin{array}{l}\text { Cross-sectional study. } \\
\mathrm{N}=451 \text { people }\end{array}$ & - Filling out a pain diary. & $\begin{array}{l}\text { Pain management today } \\
\text { predicts decreased pain the } \\
\text { next day. Negativity and } \\
\text { coping are not related to the } \\
\text { level of pain the next day. }\end{array}$ & $\mathrm{PH}$ & 4 & $\mathrm{C}$ \\
\hline $\begin{array}{l}\text { Nicholas } \\
\text { et al. } \\
2017 \\
\text { USA }\end{array}$ & $\begin{array}{l}\text { Examine the } \\
\text { interaction between } \\
\text { pain and short-term } \\
\text { physical functioning. }\end{array}$ & $\begin{array}{l}\text { Longitudinal study. } \\
\mathrm{N}=389 \text { people }\end{array}$ & $\begin{array}{l}\text { - } 15 \text {-item Brief Pain Inventory } \\
\text { - 2-item Short-Form } 36 \text { Bodily Pain } \\
\text { Scale (SF-36) }\end{array}$ & $\begin{array}{l}\text { Therapies to control the } \\
\text { consequences of chronic } \\
\text { pain in relevant aspects of } \\
\text { life and physical activities } \\
\text { are necessary for restoration } \\
\text { of vital activity. }\end{array}$ & $\mathrm{PH}$ & $2 b$ & B \\
\hline $\begin{array}{l}\text { Orhurhu } \\
\text { et al. } \\
2015 \\
\text { USA }\end{array}$ & $\begin{array}{l}\text { Determine the } \\
\text { prevalence of smoking } \\
\text { in patients with } \\
\text { chronic pain. }\end{array}$ & $\begin{array}{l}\text { Population study } \\
\mathrm{N}=5,350 \text { patients }\end{array}$ & & $\begin{array}{l}\text { The prevalence of smoking } \\
\text { in adults with chronic pain } \\
\text { was } 23.5 \% \text {. }\end{array}$ & $\mathrm{S}$ & 4 & $\mathrm{C}$ \\
\hline $\begin{array}{l}\text { Raijmakers } \\
\text { et al. } \\
2015 \\
\text { Alemannia }\end{array}$ & $\begin{array}{l}\text { Determine differences } \\
\text { in the level of daily } \\
\text { activity between } \\
\text { people with and } \\
\text { without pain. }\end{array}$ & $\begin{array}{l}\text { Clinical trial } \\
\mathrm{N}=37 \text { people }\end{array}$ & & $\begin{array}{l}\text { Patients with chronic pain } \\
\text { have a lower overall level } \\
\text { of physical activity than the } \\
\text { healthy population. }\end{array}$ & $\mathrm{PH}$ & $1 b$ & A \\
\hline $\begin{array}{l}\text { Stefane } \\
\text { et al. } \\
2013 \\
\text { Brazil }\end{array}$ & $\begin{array}{l}\text { Evaluate perceived } \\
\text { pain, disability and } \\
\text { quality of life in } \\
\text { individuals with } \\
\text { chronic low back pain. }\end{array}$ & $\begin{array}{l}\text { Cross-sectional study. } \\
\mathrm{N}=97 \text { people }\end{array}$ & $\begin{array}{l}\text { - } \text { Roland Morris } \\
\text { Questionnaire (RMQ) } \\
\text { - WHOQOL-Brief }\end{array}$ & $\begin{array}{l}\text { The perceived score of } \\
\text { pain intensity, disability } \\
\text { and quality of life were the } \\
\text { most affected. }\end{array}$ & $\begin{array}{l}\text { ADL, } \\
\text { SP }\end{array}$ & 4 & $\mathrm{C}$ \\
\hline $\begin{array}{l}\text { Triñanes } \\
\text { et al. } \\
2014 \\
\text { Spain }\end{array}$ & $\begin{array}{l}\text { Describe the } \\
\text { relationship of } \\
\text { suicidal ideation in } \\
\text { fibromyalgia. }\end{array}$ & $\begin{array}{l}\text { Cross-sectional study. } \\
\mathrm{N}=117 \text { women }\end{array}$ & $\begin{array}{l}\text { - Beck Depression Inventory (BDI) } \\
\text { - The Pittsburgh Sleep Quality } \\
\text { Index (PSQI) } \\
\text { - The Fibromyalgia Impact } \\
\text { Questionnaire (FIQ) } \\
\text { - Short-Form } 36 \text { Health } \\
\text { Survey (SF-36) } \\
\text { - Visual Analogue Scale (VAS) }\end{array}$ & $\begin{array}{l}\text { Patients with fibromyalgia } \\
\text { have a moderate level } \\
\text { of depression, sleep } \\
\text { dysfunction and severe } \\
\text { deterioration in different } \\
\text { functional areas and } \\
\text { well-being. } 32.5 \% \text { expressed } \\
\text { suicidal ideation or } \\
\text { suicide attempt. }\end{array}$ & $\mathrm{S}$ & 4 & $\mathrm{C}$ \\
\hline $\begin{array}{l}\text { Walker } \\
\text { et al. } \\
2013 \\
\text { USA }\end{array}$ & $\begin{array}{l}\text { Determine whether } \\
\text { or not there is a } \\
\text { statistically significant } \\
\text { relationship between } \\
\text { pain severity and life } \\
\text { satisfaction in patients } \\
\text { with chronic pain. }\end{array}$ & $\begin{array}{l}\text { Cross-sectional study. } \\
\mathrm{N}=172 \text { people }\end{array}$ & $\begin{array}{l}\text { - Pain Severity Scale (PSS) } \\
\text { - West-Haven-Yale } \\
\text { Multidimensional Pain } \\
\text { Inventory (WHYMP) } \\
\text { - Satisfaction with Life Scale (SWL) } \\
\text { - Coping Responses } \\
\text { Inventory-Adult (CRI-A) }\end{array}$ & $\begin{array}{l}\text { A statistically significant } \\
\text { negative correlation was } \\
\text { observed between pain } \\
\text { severity and life satisfaction. } \\
\text { The relationship between } \\
\text { pain severity and life } \\
\text { satisfaction seems to change } \\
\text { depending on the level of } \\
\text { coping approach exhibited } \\
\text { by individuals suffering from } \\
\text { chronic pain. }\end{array}$ & $\begin{array}{l}\mathrm{ADL} \\
\mathrm{S}, \mathrm{PH}\end{array}$ & 4 & $\mathrm{C}$ \\
\hline $\begin{array}{l}\text { Wilson } \\
\text { et al. } \\
2015 \\
\text { Canada }\end{array}$ & $\begin{array}{l}\text { Describe what adults } \\
\text { with chronic pain } \\
\text { experience in their role } \\
\text { as parents. }\end{array}$ & $\begin{array}{l}\text { Qualitative. In-depth } \\
\text { interviews. } \\
N=130 \text { people }\end{array}$ & $\begin{array}{l}\text { - Brief Pain Inventory (BPI) } \\
\text { - Numerical Rating Scale (NRS) } \\
\text { - Pain Catastrophizing } \\
\text { Scale-Parent version }\end{array}$ & $\begin{array}{l}\text { Parents with chronic pain are } \\
\text { more protective and empathic } \\
\text { for children. } 81 \% \text { of parents } \\
\text { talk about their experiences } \\
\text { of pain with their children, } \\
\text { usually when they have to tell } \\
\text { them they can't do anything } \\
\text { as a result of pain. }\end{array}$ & SLFC & 5 & $\mathrm{D}$ \\
\hline
\end{tabular}


Table. Main characteristics of the studies included in the review. (Continuation)

\begin{tabular}{|c|c|c|c|c|c|c|c|}
\hline $\begin{array}{l}\text { Authors, } \\
\text { year, country }\end{array}$ & Objective & Methodology/sample & Intervention & Results & $\begin{array}{c}\text { Key } \\
\text { points }\end{array}$ & LE & DR \\
\hline $\begin{array}{l}\text { Wing et al. } \\
2016 \\
\text { France }\end{array}$ & $\begin{array}{l}\text { Examine associations } \\
\text { between chronic } \\
\text { pain and psychiatric } \\
\text { morbidity. }\end{array}$ & $\begin{array}{l}\text { Cross-sectional study. } \\
\mathrm{N}=370 \text { people }\end{array}$ & $\begin{array}{l}\text { 7-item Chronic Pain Grade } \\
\text { Questionnaire (CPG-7) } \\
\text { - Numerical Rating Scale (NRS) }\end{array}$ & $\begin{array}{l}\text { Patients with higher pain } \\
\text { intensity and interference in } \\
\text { social activities were more } \\
\text { likely to have depression and } \\
\text { anxiety. }\end{array}$ & $\mathrm{S}$ & 4 & $\mathrm{C}$ \\
\hline $\begin{array}{l}\text { Yamada } \\
\text { et al. } \\
2016 \\
\text { Japan }\end{array}$ & $\begin{array}{l}\text { Examine the } \\
\text { association between } \\
\text { psychosocial factors } \\
\text { related to work and } \\
\text { the prevalence of } \\
\text { health-related quality } \\
\text { of life. }\end{array}$ & $\begin{array}{l}\text { Cross-sectional study. } \\
\mathrm{N}=1,764 \text { people }\end{array}$ & - EuroQol-5D (EQ-5D) & $\begin{array}{l}\text { The prevalence of pain in } \\
\text { workers was higher than in } \\
\text { workers. Women had more } \\
\text { severe depressive symptoms } \\
\text { than men. }\end{array}$ & SP & 4 & $\mathrm{C}$ \\
\hline
\end{tabular}

ADL: Activities of daily living; S: sleep; PH: psychological health; SLFC: socio-labor and family consequences; LE: levels of evidence; DR: degree of recommendation.

anxiety and depression rates reach $30-40 \%$, being more pronounced in women ${ }^{13}$. Anxiety and depression cause fear of pain-enhancing activities, generating a spiral of pain, fear and avoidance $\mathrm{e}^{24,39-42}$.

Several authors highlight the relationship between adaptability and CNCP experiences. Thus, people with higher self-esteem have much less unpleasant pain stimuli, improving the use of coping strategies ${ }^{43,44}$. The findings of El-Shormilisy et al..$^{45}$ suggest that coping is also mediated by sex. Women with CNCP develop fewer adaptation strategies than men, resulting in worse functional outcomes.

On the other hand, the prevalence of suicidal ideation and suicide attempts in the population with CNCP is $20 \%$ and 5 to $14 \%$, respectively, twice the general population ${ }^{3,45-47}$. According to Campbell et al. ${ }^{3}$, this relationship may be due to many people who do not reduce the intensity of their pain, despite undergoing lifelong treatment.

The relationship between CNCP and tobacco use is also complex. According to Orhurhu et al. $.^{14}, 25.3 \%$ of people with CNCP use tobacco, twice the general population. A study by Dirtre et al. ${ }^{48}$ found that $43 \%$ of participants who used tobacco also had CNCP. These people reported tobacco use as an agent who calmed anxiety caused by pain. In this sense, the relationship between CNCP and tobacco use is dynamic. Smokers have higher pain rates, increased number of painful sites and higher levels of anxiety and depression, which would encourage tobacco use $\mathrm{e}^{14,48}$. Thus, pain would strengthen tobacco dependence that results in greater pain ${ }^{48}$.

\section{Socio-employment and family consequences}

Several studies have shown CNCP causes social isolation, decreased leisure activities and work difficulties ${ }^{20,23,47}$. However, people who have greater social participation may have better health, reduced anxiety, depression and reduced perceived stress ${ }^{23,24}$. In this sense, El-Shormilisy et al. ${ }^{11}$, claim that women and men with CNCP are differently related to their social environment. According to this author, women are socialized from an early age to express their emotions and seek social support, and men would be more likely not to do so. This could translate into greater resources to deal with the CNCP in them.

In the field of research, the existence of CNCP poses a great economic burden for the individual and the system. According to Dany et al. ${ }^{48}$, most people need to keep working despite the pain, especially in these groups with fewer resources, and they may have less productivity at work.

The family environment of people with CNCP may also be affected ${ }^{24,49}$, as it impacts the family scope, its functioning, and how its members communicate or resolve conflicts. Reactions 
from other members can trigger different types of invalid responses, rejection, and/or support $^{22}$. In this sense, difficulties with the partner contribute to increased depression and anxiety ${ }^{50}$.

Regarding parental relationships, parents model the perceptions and attitudes of their sons and daughters in the face of pain through their own experience, taking as an example the actions and discourses they observe. In turn, pain may affect parents' ability to complete physical tasks related to creation ${ }^{49}$.

\section{DISCUSSION}

The increase in scientific production on chronic pain in adulthood allowed us to characterize aspects of interest and detect new lines of research, despite having this Scoping Review as the main limitation of linguistic bias, since there were no studies published in languages other than Spanish or English.

This review shows the ability to perform activities of daily living, sleep, psychological health, labor socio-economic consequences and family functioning are lines of interest in articles published. However, knowledge gaps are detected in areas such as consequences of work, toxic consumption and gender inequalities.

There is an extensive literature on the impact of $\mathrm{CNCP}$ on functional capacity, but comorbidity with other chronic diseases is less known. Butchart et al. ${ }^{51}$, found that about $30 \%$ of people with coronary heart disease and chronic obstructive pulmonary disease (COPD) also suffer pain. Torrance et al. ${ }^{52}$ state that comorbidity between chronic pain and one of these two diseases increases by up to three times the probability of dying compared with the population who do not suffer from pain. These authors explain this relationship as a result of the decrease in the daily functioning capacity of people with CNCP. These higher rates of comorbidity, mortality and dependence result in greater use of health services and, therefore, economic expenses, as found by Pitcher et al. ${ }^{31}$, in our results. However, few studies produce actual figures on the real economic impact of CNCP. Direct and indirect costs in Europe are estimated at 200 million euros and in the US between US\$560 million and US\$635 million ${ }^{54}$.

As to psychological health, numerous authors have found that the condition of mental illness, such as anxiety or depression in people with CNCP, is common. Knowing this relationship is important, because authors such as Rayner et al. ${ }^{55}$ report that an effective approach and treatment of depression and anxiety in people with CNCP can improve their health by up to $14 \%$, reducing thus functional limitation and impact on health systems. On the other hand, other authors consider this relationship inverse, that is, chronic pain would be one of the first consequences of mental illness ${ }^{56-59}$. However, for authors such as Von Korff et al. ${ }^{60}$, the temporal relationship between mental illness and $\mathrm{CNCP}$ is unclear, it seems to be bidirectional and both act as a positive reinforcement for the other.

People with CNCP have higher rates of tobacco use. In our results, authors such as Catalano et al. ${ }^{13}$ and Ditre et al. ${ }^{48}$ affirm that tobacco habit increases the level of pain. However, Shi et al. ${ }^{61}$ observe that this relationship has not been shown, but they insist that depressive symptoms associated with tobacco use can increase pain levels.

No studies on the relationship between chronic pain and alcohol consumption were found. We consider it necessary to conduct research on this subject considering the results obtained by Riley \& King ${ }^{62}$ in 2009, in which they show that alcohol may be used to relieve pain by its transient analgesic effect. Some results contradict the Danish cohort study by Ekholm et al. ${ }^{63}$, concluding that patients with $\mathrm{CNCP}$ are less likely to consume alcohol, but it is risky when mixed with the drug ${ }^{64}$. 
Regarding labor consequences, the loss of work and the economic cost that generates pain are little studied. Yamada et al. ${ }^{65}$ claim that people with CNCP may have lower productivity rates, which would be a heavy economic burden. In this sense, Pain Proposal's results support this statement, adding that $21 \%$ of the population with CNCP felt unable to finish their working day, which translates into an impact on the labor market of 2.5 million euros and 52 million of lost working days per year ${ }^{10}$. They also indicate that in Spain, the average number of days lost due to pain is 16.8 days a year ${ }^{66}$.

Regarding gender inequalities, research shows that, as in other clinical pathologies, women receive more precarious health care than men $^{67}$. Several studies have found great differences in subjective perception of pain or general well-being in women, despite having scores similar to those of men in analytical and radiological data, which may lead us to think that it is devaluing itself with the use of clinical indices that do not reflect the women's reality. In addition, the authors emphasize the importance of gender analysis in the study of $\mathrm{CNCP}^{68}$. In this review, the studies found prevalence data disaggregated by sex, and some, in a transversal way, identify differences in male and female experiences, but do not analyze them from a gender perspective ${ }^{69}$.

\section{REFERENCIAS}

1. International Association for the Study of Pain (IASP). Classification of chronic pain: descriptions of chronic pain syndromes and definitions of pain terms. 2. ed. Seattle (USA): IASP Press; 1986.

2. Blyth FM, Windt DA, Croft PR. Chronic disabling pain. Am J Prev Med. 2017;49(1):98-101. https://doi.org/10.1016/j.amepre.2015.01.008

3. Campbell G, Darke S, Bruno R, Degenhardt L. The prevalence and correlates of chronic pain and suicidality in a nationally representative sample. Aust N Z J Psychiatry. 2015;49(9):803-11. https://doi.org/10.1177/0004867415569795

4. Castro A, Gili M, Aguilar JL, Pélaez R, Roca M. Sueño y depresión en una muestra de pacientes con dolor crónico. Rev Soc Esp Dolor. 2014;21(6):299-306. https://doi.org/10.4321/S1134-80462014000600002

5. Sola H, Salazar A, Dueñas M, Ojeda B, Failde I. A nationwide cross-sectional study of the impact of chronic pain on an individual's employment: relationship with the family and the social support. BMJ Open. 2016;6(12):e012246. https://doi.org/10.1136/bmjopen-2016-012246

6. Cabrera-León A, Rueda M, Cantero-Braojos M. Calibrated prevalence of disabling chronic pain according to different approaches: a face-to-face cross-sectional population-based study in Southern Spain. BMJ Open. 2017;7:e014033. https://doi.org/10.1136/bmjopen-2016-014033

7. Jonsdottir T, Aspelund T, Jonsdottir H, Gunnarsdottir S. The relationship between chronic pain pattern, interference with life and health-related quality of life in a nationwide community sample. Pain Manag Nurs. 2014;15(3):641-51. https://doi.org/10.1016/j.pmn.2013.07.005

8. Von Korff M, Dunn KM. Chronic pain reconsidered. Pain. 2008;138(2):267-76. https://doi.org/10.1016/j.pain.2007.12.010

9. Tsang A, Von Korff M, Lee S, Alonso J, Karam E, Angermeyer MC, et al. Common chronic pain conditions in developed and developing countries: gender and age differences and comorbidity with depression-anxiety disorders. J Pain. 2008;9(10):883-91. https://doi.org/10.1016/j.jpain.2008.05.005

10. Torralba A, Miquel A, Darba J. Situación actual del dolor crónico en España: iniciativa "Pain Proposal". Rev Soc Esp Dolor. 2014;21(1):16-22. https://doi.org/10.4321/S1134-80462014000100003

11. Amaya-Ropero MC, Carrillo-González GM. Apoyo social percibido y afrontamiento en personas con dolor crónico no maligno. Aquichan. 2015;15(4):461-74. https://doi.org/10.5294/aqui.2015.15.4.2

12. Reid MC, Williams CS, Gill TM. The relationship between psychological factors and disabling musculoskeletal pain in community-dwelling older persons. J Am Geriatr Soc. 2003;51(8):1092-8. https://doi.org/10.1046/j.1532-5415.2003.51357.x

13. Olivares-Crespo ME, Cruzado-Rodríguez JA. Evaluación psicológica del dolor. Clin Salud. 2008 [citado 09 feb 2019];19(3):321-41. Disponible en: http://scielo.isciii.es/scielo.php?script=sci_ arttext\&pid=S1130-52742008000300004 
14. Catalano D, Chan F, Wilson L, Chiu CY, Muller VR. The buffering effect of resilience on depression among individuals with spinal cord injury: a structural equation model. Rehabil Psychol. 2011;56(3):200-11. https://doi.org/10.1037/a0024571

15. Orhurhu VJ, Pittelkow TP, Hooten WM. Prevalence of smoking in adults with chronic pain. Tob Induc Dis. 2015;13(1):15-20. https://doi.org/10.1186/s12971-015-0042-y

16. Manchado-Garabito R, Tamames-Gómez S, López-González M, Mohedano-Macías L, D’Agostino M, Veiga-de Cabo J. Revisiones sistemáticas exploratorias. Med Segur Trab. 2009 [citado 27 ene 2019];55(216):12-19. Disponible en: http://scielo.isciii.es/scielo.php?script=sci_arttext\&pid=S0 465-546X2009000300002\&lng=es

17. Arksey H, O'Malley L. Scoping studies: towards a methodological framework. Int J Soc Res Methodol. 2005;8(1):19-32. https://doi.org/10.1080/1364557032000119616

18. The Joanna Briggs Institute. Joanna Briggs Institute reviewer's manual 2015: methodology for JBI scoping reviews. Adelaide (AUS); 2015 [citado 18 dic 2018]. Disponible en: https://joannabriggs.org/assets/docs/sumari/ReviewersManual Methodology-for-JBI-ScopingReviews 2015 v2.pdf

19. Bellomo R, Bagshaw SM. Evidence-based medicine: classifying the evidence from clinical trials: the need to consider other dimensions. Crit Care. 2006;10(5):232. https://doi.org/10.1186/cc5045

20. Armstrong R, Hall BJ, Doyle J, Waters E. 'Scoping the scope' of a Cochrane review. J Public Health. 2011;33(1):147-50. https://doi.org/10.1093/pubmed/fdr015

21. Harbour R, Miller J. A new system for grading recommendations in evidence based guidelines. BMJ. 2001;323(7308):334-6. https://doi.org/10.1136/bmj.323.7308.334

22. Akbari F, Dehghani M, Khatibi A, Vervoort T. Incorporating family function into chronic pain disability: the role of catastrophizing. Pain Res Manag. 2016;2016:6838596. https://doi.org/10.1155/2016/6838596

23. Inoue $S$, Kobayashi F, Nishihara M, Arai YC, Ikemoto T, Kawai T, et al. Chronic pain in the Japanese community: prevalence, characteristics and impact on quality of life. PLoS One. 2015;10(6):e0129262. https://doi.org/10.1371/journal.pone.0129262

24. Cabrera-Perona V, Buunk AP, Terol-Cantero MC, Quiles-Marcos Y, Martín-Aragón M. Social comparison processes and catastrophising in fibromyalgia: a path analysis. Psychol Health. 2017;32(6):745-64. https://doi.org/10.1080/08870446.2017.1307370

25. Kawai K, Kawai AT, Wollan P, Yawn BP. Adverse impacts of chronic pain on health-related quality of life, work productivity, depression and anxiety in a community-based study. Fam Pract. 2017;34(6):656-61. https://doi.org/10.1093/fampra/cmx034

26. Jensen HI, Plesner K, Kvorning N, Krogh BL, Kimper-Karl A. Associations between demographics and health-related quality of life for chronic non-malignant pain patients treated at a multidisciplinary pain centre: a cohort study. Int J Qual Health Care. 2016;28(1):86-91. https://doi.org/10.1093/intqhc/mzv108

27. Jones JD, Vogelman JS, Luba R, Mumtaz M, Comer SD. Chronic pain and opioid abuse: factors associated with health-related quality of life. Am J Addict. 2017;26(8):815-21. https://doi.org/10.1111/ajad.12637

28. Bailly F, Foltz V, Rozenberg S, Fautrel B, Gossec L. The impact of chronic low back pain is partly related to loss of social role: a qualitative study. Joint Bone Spine. 2015;82(6):437-41. https://doi.org/10.1016/j.jbspin.2015.02.019

29. Mun CJ, Thummala K, Davis MC, Karoly P, Tennen H, Zautra AJ. Predictors and social consequences of daily pain expectancy among adults with chronic pain. Pain. 2017;158(7):1224-33. https://doi.org/10.1097/j.pain.0000000000000903

30. Raijmakers BG, Nieuwenhuizen MG, Beckerman H, Groot S. Differences in the course of daily activity level between persons with and without chronic pain. Am J Phys Med Rehabil. 2015;94(2):101-13. https://doi.org/10.1097/PHM.0000000000000206

31. Pitcher MH, Von Korff M, Bushnell MC, Porter L. Prevalence and profile of high-impact chronic pain in the United States. J Pain. 2019;20(2):146-60. https://doi.org/10.1016/j.jpain.2018.07.006

32. Ojala T, Häkkinen A, Karppinen J, Sipilä K, Suutama T, Piirainen A. Chronic pain affects the whole person: a phenomenological study. Disabil Rehabil. 2015;37(4):363-71. https://doi.org/10.3109/09638288.2014.923522

33. McCracken LM, Barker E, Chilcot J. Decentering, rumination, cognitive defusion, and psychological flexibility in people with chronic pain. J Behav Med. 2014;37(6):1215-25 https://doi.org/10.1007/s10865-014-9570-9 
34. Karaman S, Karaman T, Dogru S, Onder Y, Citil R, Bulut YE, et al. Prevalence of sleep disturbance in chronic pain. Eur Rev Med Pharmacol Sci. 2014;18(17):2475-81.

35. Campbell P, Tang N, McBeth J, Lewis M, Main CJ, Croft PR, et al. The role of sleep problems in the development of depression in those with persistent pain: a prospective cohort study. Sleep. 2013;36(11):1693-8. https://doi.org/10.5665/sleep.3130

36. Andrews NE, Strong J, Meredith PJ, D’Arrigo RG. Association between physical activity and sleep in adults with chronic pain: a momentary, within-person perspective. Phys Ther. 2014;94(4):499-510. https://doi.org/10.2522/ptj.20130302

37. Crandford JA, Arnedt TO, Conroy DA, Bohnert KM, Bourque C, Blow FC, et al. Prevalence and correlates of sleep-related problems in adults receiving medical cannabis for chronic pain. Drug Alcohol Depend. 2017;180:227-33. https://doi.org/10.1016/j.drugalcdep.2017.08.017

38. Robertson JA, Purple RJ, Cole P, Zaiwalla Z, Wulff K, Pattinson KTS. Sleep disturbance in patients taking opioid medication for chronic back pain. Anaesthesia. 2016;71(11):1296-307. https://doi.org/10.1111/anae.13601

39. Wong WS, Chen PP, Yap J, Mak KH, Tam BK, Fielding R. Chronic pain and psychiatric morbidity: a comparison between patients attending specialist orthopedics clinic and multidisciplinary pain clinic. Pain Med. 2011;12(2):246-59. https://doi.org/10.1111/j.1526-4637.2010.01044.x

40. Craner JR, Gilliam WP, Sperry JA. Rumination, magnification, and helplessness: how do different aspects of pain catastrophizing relate to pain severity and functioning? Clin J Pain. 2016;32(12):1028-35. https://doi.org/10.1097/AJP.0000000000000355

41. Boggero IA, Carlson CR. Somatosensory and affective contributions to emotional, social, and daily functioning in chronic pain patients. Pain Med. 2015;16(2):341-7. https://doi.org/10.1111/pme.12598

42. Altug F, Kavlak E, Kurtca MP, Ünal A, Cavlak U. Comparison of pain intensity, emotional status and disability level in patients with chronic neck and low back pain. J Back Musculoskelet Rehabil. 2015;28(3):505-8. https://doi.org/10.3233/BMR-140548

43. Ferreira-Valente MA, Pais-Ribeiro JL, Jensen MP. Associations between psychosocial factors and pain intensity, physical functioning, and psychological functioning in patients with chronic pain: a cross-cultural comparison. Clin J Pain. 2014;30(8):713-23. https://doi.org/10.1097/AJP.0000000000000027

44. Walker S, Esterhuyse K. Pain severity, coping and satisfaction with life in patients with chronic pain. South African J Anaesth Analg. 2013;19(5):252-6. https://doi.org/10.1080/22201173.2013.10872935

45. El-Shormilisy N, Strong J, Meredith PJ. Associations among gender, coping patterns and functioning for individuals with chronic pain: a systematic review. Pain Res Manag. 2015;20(1):48-55. https://doi.org/10.1155/2015/490610

46. Calandre EP, Navajas-Rojas MA, Ballesteros J, Garcia-Carillo J, Garcia-Leiva JM, Rico-Villademoros F. Suicidal ideation in patients with fibromyalgia: a cross-sectional study. Pain Pract. 2014;15(2):168-75. https://doi.org/10.1111/papr.12164

47. Triñanes Y, González-Villar A, Gómez-Perretta C, Carrillo-de la Peña MT. Suicidality in chronic pain: predictors of suicidal ideation in fibromyalgia. Pain Pract. 2015;15(4):323-32. https://doi.org/10.1111/papr.12186

48. Ditre JW, Zale EL, Kosiba JD, Zvolensky MJ. A pilot study of pain-related anxiety and smoking dependence motives among persons with chronic pain. Exp Clin Psychopharmacol. 2013;21(6):443-9. https://doi.org/10.1037/a0034174

49. Wilson AC, Fales JL. Parenting in the context of chronic pain: a controlled study of parents with chronic pain. Clin J Pain. 2015;31(8):689-98. https://doi.org/10.1097/AJP.0000000000000157

50. Henne E, Morrissey S, Conlon E. An investigation into the relationship between persistent pain, psychological distress and emotional connectedness. Psychol Health Med. 2015;20(6):710-9. https://doi.org/10.1080/13548506.2014.986142

51. Butchart A, Kerr EA, Heisler M, Piette JD, Krein SL. Experience and management of chronic pain among patients with other complex chronic conditions. Clin J Pain. 2009;25(4):293-8. https://doi.org/10.1097/AJP.0b013e31818bf574

52. Torrance N, Elliott AM, Lee AJ, Smith BH. Severe chronic pain is associated with increased 10 year mortality: a cohort record linkage study. Eur J Pain. 2010;14(4):380-6. https://doi.org/10.1016/j.ejpain.2009.07.006

53. Barham L. Economic burden of chronic pain across Europe. J Pain Palliat Care Pharmacother. 2012;26(1):70-2. https://doi.org/10.3109/15360288.2011.650364 
54. Gaskin DJ, Richard P. The economic costs of pain in the United States. En: Institute of Medicine (US), Committee on Advancing Pain Research, Care, and Education. Relieving pain in America: a blueprint for transforming prevention, care, education, and research. Washington, DC: National Academies Press; 2011. p.55-112

55. Rayner L, Hotopf M, Petkova H, Matcham F, Simpson A, McCraken LM. Depression in patients with chronic pain attending a specialised pain treatment centre: prevalence and impact on health care costs. Pain. 2016;157(7):1472-9. https://doi.org/10.1097/j.pain.0000000000000542

56. Boersma K, Linton S. Expectancy, fear and pain in the prediction of chronic pain and disability: a prospective analysis. Eur J Pain. 2006;10(6):551-7. https://doi.org/10.1016/j.ejpain.2005.08.004

57. Windt D, Croft P, Penninx B. Neck and upper limb pain: more pain is associated with psychological distress and consultation rate in primary care. J Rheumatol. 2002;29(3):564-9

58. Windt D, Kuijpers T, Jellema P, Heijden GJ, Bouter LM. Do psychological factors predict outcome in both low-back pain and shoulder pain? Ann Rheum Dis. 2007;66(3):313-9. https://doi.org/10.1136/ard.2006.053553

59. Nijrolder I, Windt D, Horst H. Prediction of outcome in patients presenting with fatigue in primary care. Br J Gen Pract. 2009;59(561):e101-9. https://doi.org/10.3399/bjgp09X420329

60. Von Korff M, Le Resche L, Dworkin SF. First onset of common pain symptoms: a prospective study of depression as a risk factor. Pain. 1993;55(2):251-8. https://doi.org/10.1016/0304-3959(93)90154-H

61. Shi Y, Weingarten TN, Mantilla CB, Hooten WM, Warner DO. Smoking and pain: pathophysiology and clinical implications. Anesthesiology. 2010;113(4):977-92. https://doi.org/10.1097/ALN.0b013e3181ebdaf9

62. Riley JL 3rd, King C. Self-report of alcohol use for pain in a multi-ethnic community sample. J Pain. 2009;10(9):944-52. https://doi.org/10.1016/j.jpain.2009.03.005

63. Ekholm O, Grønbaek M, Peuckmann V, Sjøgren P. Alcohol and smoking behavior in chronic pain patients: the role of opioids. Eur J Pain. 2009;13(6):606-12. https://doi.org/10.1016/j.ejpain.2008.07.006

64. Brennan PL, Schutte KK, Moos RH. Pain and use of alcohol to manage pain: prevalence and 3-year outcomes among older problem and non-problem drinkers. Addiction. 2005;100(6):777-86. https://doi.org/10.1111/j.1360-0443.2005.01074.x

65. Yamada K, Matsudaira K, Imano H, Kitamura A, Iso H. Influence of work-related psychosocial factors on the prevalence of chronic pain and quality of life in patients with chronic pain. BMJ Open. 2016;25:6(4):e010356. https://doi.org/10.1136/bmjopen-2015-010356

66. Caramés-Álvarez MA, Navarro-Rivera M. Costes del tratamiento del dolor versus su no tratamiento. Aproximación a la realidad de Portugal y España. Dor. 2016,24. [13 mar 2019]. Disponible en: https://www.sedolor.es/download/costes-del-tratamiento-del-dolor-versus-notratamiento-aproximacion-la-realidad-portugal-espana/

67. Hampton SB, Cavalier J, Langford R. The influence of race and gender on pain management: a systematic literature review. P Manag Nurs. 2015;16(6):968-77. https://doi.org/10.1016/j.pmn.2015.06.009

68. Lumley MA, Cohen JL, Borszcz GS, Cano A, Radcliffe AM, Porter LS, et al. Pain and emotion: a biopsychosocial review of recent research. J Clin Psychol. 2011;67(9):942-68. https://doi.org/10.1002/jclp.20816

69. Wranker L, Rennemark M, Berglund J, Elmstâhl S. Relationship between pain and Quality of Life Findings from the Swedish National Study on Aging and Care-Blekinge study. Scan J Pain. 2014;5(4):270-275. https://doi.org/10.1016/j.sjpain.2014.05.029

70. Cáceres-Matos R, Gil-García E, Barrientos-Trigo S, Molina E, Porcel-Gálvez AM. Consecuencias del dolor crónico en la infancia y la adolescencia. Gac Sanit. 2019;33(3):272-82. https://doi.org/10.1016/j.gaceta.2017.11.007

Funding: This study is framed in a doctoral thesis funded by a pre-doctorate grant of the University Professors Training Program (FPU) of the Ministry of Innovation, Science and Universities of the Government of Spain.

Authors' contributions: Study conception and approach: RCM, EGG. Data collection: RCM, SBST. Data analysis and interpretation: RCM, EGG, SBT, ACL, AMPG. Preparation and writing of the study: RCM, EGG. Critical review of the study: RCM, EGG, SBT, ACL, AMPG. Approval of the final version: RCM, EGG, SBT, ACL, AMPG.

Conflict of Interest: The authors declare no conflicts of interest. 